\title{
School Library Advocacy Literature in the United States: An Exploratory Content Analysis
}

\section{Authors: Ann D. Ewbank \& Ja Youn Kwon}

NOTICE: this is the author's version of a work that was accepted for publication in Library and Information Science Research. Changes resulting from the publishing process, such as peer review, editing, corrections, structural formatting, and other quality control mechanisms may not be reflected in this document. Changes may have been made to this work since it was submitted for publication. A definitive version was subsequently published in Library and Information Science Research, VOL\# 37, ISSUE\# 3, July 2015 DOI\# 10.1016/j.lisr.2015.04.005

Ewbank, Ann D. \& Kwon, Ja Youn (2015). School Library Advocacy Literature in the United States: An Exploratory Content Analysis. Library and Information Science Research 37(3), 236-243. doi: 10.1016/j.lisr.2015.04.005.

Made available through Montana State University's ScholarWorks scholarworks.montana.edu 


\title{
School library advocacy literature in the United States: An exploratory content analysis
}

\author{
Ann Dutton Ewbank ${ }^{\mathrm{a}, *}$, Ja Youn Kwon ${ }^{\mathrm{b}}$ \\ a College of Education, Health and Human Development, Montana State University, USA \\ ${ }^{\mathrm{b}}$ Mary Lou Fulton Teachers College, Arizona State University, USA
}

\begin{abstract}
A B S T R A C T
This exploratory conceptual content analysis describes the published school library advocacy literature in the United States from 2001-2011. In 47 articles, the advocacy efforts undertaken, the responsible parties, the target populations, and goals and reasons for advocacy were examined. In all, 372 separate advocacy efforts were found. Of these, 168 efforts outlined tangible results of advocacy efforts while 204 efforts described strategies or techniques for advocacy but did not identify an outcome. The general school community was the most predominant target population for advocacy. Advocacy efforts specifically targeting school administrators and teachers were an infrequent target. The advocacy goal mentioned most frequently in the literature was enhancing awareness. Most (83\%) advocacy activities were initiated by school librarians or an individual in the school library field. School library researchers should address the dearth of empirical and theoretical work on both the practice and impact of advocacy on the profession.
\end{abstract}

\section{Introduction}

Advocacy for the profession is a topic of discussion in many education related fields, including school counseling (Myers \& Sweeney, 2004; Myers, Sweeney, \& White, 2002), health education (Tappe \& Galer-Unti, 2001), music education (Mark, 2005), and physical education (Boyce \& Rikard, 2008; Gard \& Wright, 2001). There is a significant body of practitioner literature about school library advocacy. However, a thorough search of multiple databases revealed only one empirical article on school library advocacy (Ewbank, 2011). It appears that the topic of school library advocacy is virtually unanalyzed. Through an exploratory conceptual content analysis, this article describes themes and concepts in the United States published school library advocacy literature between 2001-2011.

Advocacy is defined as "a kind of political action addressed to a governing body with the aim of influencing public policy outputs" (von Winter, 2011, p. 29). Several library associations have developed expanded and contextualized definitions of advocacy. These definitions are provided in Table 1.

This study utilizes AASL's operational definition of advocacy. The American Association of School Librarians' definition is primarily concerned with building partnerships and alliances so that others may act on behalf of the school library program. The AASL's focus on advocacy

\footnotetext{
* Corresponding author at: Montana State University, P.O. Box 172880, Bozeman, MT 59717-2880, USA.

E-mail address: ann.ewbank@montana.edu (A.D. Ewbank).
}

is in response to the declining rate of school librarians in the United States, where only $64 \%$ of K-12 public schools in the United States employ a state certified librarian (http://keithcurrylance.com/2010national-statistics-on-librarian-positions-by-school-district/) and in some areas of the country, the percentage is markedly less.

The American Library Association (ALA) and the American Association of School Librarians (AASL) advocate for school libraries and librarians at the federal level. Advocacy around the pending reauthorization of the Elementary and Secondary Education Act (also known as No Child Left Behind), U.S. federal legislation that greatly influences education policy in the United States, is one example. The associations also advocated for maintaining dedicated funding for the national Improving Literacy through School Libraries program, which establishes U.S. state goals of having a school library staffed by a licensed school librarian in each public school, and allows state and local professional development funds to be used for recruiting and training school librarians (http:// www.ala.org/advocacy/advleg/federallegislation/eduleg/schoollibraries).

Furthermore, the ALA worked with Rep. Jack Reed (Democrat, Rhode Island) and Rep. Raul Grijalva (Democrat, Arizona) to re-introduce the Strengthening Kids' Interest in Learning and Libraries (SKILLS) act in 2011. This is one of the most recent advocacy attempts by the American Library Association (ALA, 2011a). Other national advocacy initiatives recently taken up include President Barack Obama's proposed American Jobs Act (ALA, 2011b), which allocates USD \$30 billion for K-12 education. Some of the funds can be applied to school libraries and librarians. Another advocacy initiative involves the U.S. National Broadband Plan, preserving E-Rate funding (a discount provided to schools and libraries for 
Table 1

Definitions of advocacy.

\begin{tabular}{|c|c|}
\hline Library Association & Definition of Advocacy \\
\hline $\begin{array}{l}\text { Canadian Association of Public Libraries (2001) } \\
\text { http://www.cla.ca/divisions/capl/advocacy/ }\end{array}$ & $\begin{array}{l}\text { Advocacy is a planned, deliberate, sustained effort to raise awareness of an issue. It's an } \\
\text { ongoing process in which support and understanding are built incrementally over an extended } \\
\text { period of time. }\end{array}$ \\
\hline $\begin{array}{l}\text { Australian School Library Association (2005) } \\
\text { http://www.kb.com.au/news/advocacy-for-school-libraries.htm }\end{array}$ & $\begin{array}{l}\text { Advocacy attempts to influence the perceptions of the target audience by connecting with } \\
\text { their agenda to demonstrate how the school library and the services of the teacher-librarian } \\
\text { can advance the position of the school as an information literate learning community. }\end{array}$ \\
\hline $\begin{array}{l}\text { American Association of School Librarians (2005) } \\
\text { http://www.ala.org/ala/mgrps/divs/aasl/aaslissues/advocacy/definitions.cfm }\end{array}$ & $\begin{array}{l}\text { Advocacy is the on-going process of building partnerships so that others will act for and with } \\
\text { you, turning passive support into educated action for the library media program. }\end{array}$ \\
\hline
\end{tabular}

telecommunications). The American Library Association actively solicited comments and feedback regarding the formation of a national Digital Literacy Corps (ALA, 2012).

Despite the focus on advocacy, in almost every state in the U.S., school librarian eliminations continue (http://goo.gl/maps/vEkH). There is a dearth of research on whether advocacy increases the likelihood of retaining librarian positions and promotes the value of the school library program staffed by a credentialed librarian. The impact of school library advocacy by individual school librarians or other stakeholders is not known. Furthermore, the impact of library associations' advocacy for the profession remains unexamined. An exploratory content analysis of the current literature is the first step in analyzing the phenomenon of school library advocacy.

\section{Problem statement}

To date, the literature on school library advocacy has been unanalyzed. Julien, Pecoskie and Reed (2011, p. 19) contend that "[content analysis] research... can be expected to motivate discussion about progress in the area and about ways in which to promote further growth in directions agreed upon by the scholarly community. Researchers can identify models to improve their work and identify trends". This study aims to establish an understanding of school library advocacy as outlined in the current literature. A study such as this has not been undertaken, and thus may provide a needed perspective as scholars in the field continue to explore school library advocacy. The research questions guiding the study are:

1. What advocacy efforts are being undertaken?

2. Who is responsible for advocacy?

3. Who are the target populations of advocacy?

4. What are the goals of advocacy?

5. What are the reasons for advocacy?

\section{Literature review}

\subsection{Organizational evolution as a framework for advocacy}

Advocacy is one of the means that humans have developed to intervene in the evolutionary processes of organizational systems (March, 1994). Organizational systems evolve when there is disequilibrium in their environments (Baum \& Singh, 1994). When organizational systems question the assumptions, policies, and values that led to a problem, learning through change occurs with repeated attempts are made to solve a problem. Advocacy is a problem-solving process for the entire system. When actors encounter a threat to the library program, they sometimes attempt to solve this problem with advocacy activities.

However, advocacy can be an uphill battle. Barriers to change in schools include the failure to recognize the vulnerability of the change process to powerful cultural influences (Dooley, 1995). Organizational culture consists of "deeply embedded patterns of organizational behavior and the shared values, assumptions, beliefs, or ideologies that members have about their organization or its work" (Peterson \& Spencer, 1991, p. 142).
The U.S. public school system is multi-layered and multi-faceted. Federal policies propel change at the national level, individual states are responsible for implementing change, and within states, local entities (school districts) manifest this change and make decisions about how to best educate students. This results in a complex organizational system in which advocacy is undertaken. There are instances of advocacy at the federal, state, and local levels. Most individuals have had some interaction with the public school system (most commonly as a student), and therefore have a stake in creating its culture. However, this is one of the many factors that give rise to citizens being interested in its values and how it plays out in the societal context. For example, citizens may be interested in the success of the public school system as a driver of economic development or as a facilitator of democratic values. Citizens may be interested in advocacy for school libraries for these and other reasons. Therefore, organizational evolution is a complex enterprise in the U.S. public school system, as it is made up of many separate entities. Individuals may be interested and engage in advocacy at the local, state, or federal level.

\subsection{Research on advocacy for the professions}

Numerous educational researchers have studied the role of advocacy in their respective professions. This section will review the existing literature on advocacy for similar professions, including school counseling, health education, music education, physical education, and school libraries. These professions are analogous to school librarianship because they are often marginalized within the K-12 public school system (Dodds, 2006; Elpus, 2007; Myers \& Sweeney, 2004) and are among the first positions to be eliminated when a financial crisis occurs.

School counseling has a robust empirical literature base on advocacy for the profession. The American Counseling Association endorsed its advocacy competencies in 2003 (http://www.counseling.org/Resources/ Competencies/Advocacy_Competencies.pdf). The competencies have three levels: the client/student level, the school/community level and the public area level, where "advocacy... requires the use of technology skills, an understanding of systems, and the ability to develop relationships with various constituencies" (Ratts, DeKruyf, \& Chen-Hayes, 2007).

The school counseling profession has a long history of client advocacy rooted in social justice (Kiselica \& Robinson, 2001). In 1997, Eriksen highlighted the dearth of research on advocacy relative to the counseling profession. As a result, more attention has turned to advocacy in the counseling literature. Eriksen (1999) then conducted a study to define an initial understanding of counselor advocacy. She interviewed 28 counseling professionals who were advocates. The counseling professionals indicated two elements essential for advocacy: first, that counselors use the same attributes in advocacy that make them excellent counselors (such as relationship-building, effective communication, and inclusiveness), and second, that a clear sense of professional identity be established. Since Eriksen's initial study, various studies on school counseling advocacy for the profession have been conducted (e.g. Clemens, Shipp, \& Kimbel, 2011; Dodson, 2009; Field \& Baker, 2004; Holmberg, 2012; Kircher, 2007).

Furthermore, Myers and Sweeney (2004) conducted a national survey on advocacy for the counseling profession. They anticipated that the 
results would help to form a baseline against which future advocacy activities could be analyzed. They found that counselors believed that the lack of public understanding about what counselors do was an important issue. This survey was modified for use with school librarians (Ewbank, 2011). School librarians $(\mathrm{N}=381)$ were surveyed regarding present advocacy efforts, needs, obstacles, and successful methods. Almost all respondents testified to the importance of advocacy for the profession. However, only half of the respondents reported engaging in advocacy activities. Respondents who reported position or funding threats were more likely to advocate and perceive a greater level of success in their advocacy efforts. The most frequent obstacles to advocacy were lack of time and lack of awareness.

In physical and health education, little research on advocacy is available, although many studies have policy implications (Dodds, 2006). This is analogous to school librarianship in that the oft-cited "impact studies" (see http://www.lrs.org/impact.php) are not about the study of advocacy itself but rather, advocacy seems to be a secondary rationale for the studies, in that the studies demonstrate the importance of school libraries through evidence that ties them to desired outcomes in education, such as higher test scores, which can then be used to influence policymakers. Those studies that do have policy implications cite the relationship between physical activity and student achievement (Stanec, 2008), the justification of physical education through using neuroscience (Berg, 2010) or the importance of physical education policy on public health (Blankenship \& Solmon, 2004; Trost \& van der Mars, 2009).

In music education, little research has been conducted on advocacy but there are numerous practitioner articles about advocacy (e.g. Benham, 2011; Block, 2010; Hill, 2002; Mark, 2005; Thickstun, 2011). Mark (2002) chronicled the history of music education advocacy. Elpus contends that "we, as a profession, have been unable to relent in our efforts to convince the policymakers at the local, state, and national levels of the importance of music education in the schools" (2007, p. 13).

In the school library literature, advocacy is a frequent topic. A review of the practitioner literature on school library advocacy consists of strategies and techniques for advocacy (e.g., Bush, 2007; Hainer, 2005; Leverett, 2001; Schuckett, 2005; Williams, 2006) using evidencebased practice as an advocacy tool (e.g. Asselin, 2002; Braxton, 2003; Loertscher \& Todd, 2003; Logan, 2006; Todd, 2003, 2006, 2008a, 2008b) and reports of successful advocacy initiatives (e.g., Burris, 2006; Giambra, 1998; Kenney, 2008; Russell, 2004).

The literature on advocacy for the counseling, music education, and physical education professions mirror common issues in school librarianship. For example, a common complaint among librarians is that policymakers and other stakeholders do not understand the importance of a school librarian (Hainer, 2005), which music educators describe as an issue for their profession as well. Similarly, physical education professionals have attempted to convince policymakers about their importance by developing a corpus of literature that links physical education with student achievement and public health. In the section that follows, we illustrate how a similar case is made for school libraries and certified librarians through research.

\subsection{The case for school libraries}

A significant body of literature, spanning nearly fifty years, indicates that school librarians and school library programs have an impact on student achievement (Gaver, 1963; Ireland, 2001). Since 1993, a number of studies have demonstrated that a well-developed school library program staffed with a qualified or credentialed school librarian has a positive impact on student achievement. These studies represent a body of evidence that advocates frequently draw upon to demonstrate the value of school library programs (see http://library.mansfield.edu/ impact.asp and http://www.lrs.org/impact.php for an accounting of these studies). Several of these studies are reviewed in this section.

Perhaps the most drawn upon studies are those that correlate school library staffing with increased student achievement. The New York
(Small, Shanahan, \& Stasak, 2010) study found that elementary students in schools with a certified school librarian were more likely to achieve higher scores on English Language Arts standardized tests than their counterparts in schools without certified librarians. Similar results were found in Illinois (Lance, Rodney, \& Hamilton-Pennell, 2005), Michigan (Rodney, Lance, \& Hamilton-Pennell, 2003), Ontario, Canada (Ontario Library Association, 2006), California (Farmer, 2006), and Iowa (Rodney, Lance, \& Hamilton-Pennell, 2002).

There is also evidence that collaboration between the librarian and classroom teacher is positively correlated with student achievement. Several studies demonstrate that access to current and quality library materials have an impact on student achievement. The Illinois study (Lance et al., 2005) found that students who had access to newer library collections had higher test scores. These results were also found in Texas (Smith, 2001) and Iowa (Rodney et al., 2002). Flexible scheduling, meaning that students visit the library for "just in time" learning rather than at scheduled times throughout the week, is also a factor in student achievement. Both Illinois (Lance et al., 2005) and California (Farmer, 2006) studies found that flexible scheduling was a predictor of higher reading scores on standardized tests.

Finally, the most recent school library studies at the time of this writing were conducted in New Jersey (Todd, Gordon, \& Lu, 2012) and Pennsylvania (Lance \& Schwarz, 2012). In New Jersey, this qualitative study researchers found that school librarians contribute to student success by supporting curriculum standards, including students' information literacy and students' familiarity with the research process. Librarians provide guidance on the ethical use of information and technology, and promote and foster reading as an avenue for learning (Todd et al., 2012). In Pennsylvania, the researchers found that students were two to five times more likely to score in the advanced range on state reading and writing tests if the library was well-stocked and headed by a credentialed librarian. This was true for students across socioeconomic and demographic factors (Lance \& Schwarz, 2012).

Taken together, this research base provides ample evidence for the contribution of school library programs to student achievement. This research has been used extensively in advocacy campaigns to demonstrate the need for a library staffed by a credentialed librarian in every school. ALA's Add it Up: Libraries Make the Difference in Youth Development and Education campaign (http://www.ala.org/advocacy/advleg/ advocacyuniversity/additup) provides a database of this research to assist advocates in making the case for school libraries.

\section{Method}

Content analysis has been used extensively in library science, for example, to analyze web pages (Haas \& Grams, 2000), examine the transformation of librarian jobs over time (Croneis \& Henderson, 2002; Lynch \& Smith, 2001), and to examine problem statements in the library literature (Stansbury, 2002). Marsh and White (2006) describe content analysis in library science as a "highly flexible research method (p. 22)" that uses a rigorous and systematic approach to analyze documents obtained or generated during research.

Conceptual content analysis, the methodological approach of this study, is the examination of concepts within a corpus of text. This type of content analysis involves tallying and quantifying the presence of concepts, either implicitly or explicitly stated (Beile, 2009; Busch et al., 2005; Krippendorff, 2004). Conceptual content analysis is appropriate for studies that are explanatory or descriptive in nature and when there is a theoretical reason to believe that meaning is embodied in the text units to be studied (McTavish \& Pirro, 1990). This study attempts to describe the current landscape of school library advocacy literature; therefore conceptual content analysis is an appropriate method.

The first step of this exploratory content analysis was to conduct a search of the published scholarly and practitioner literature related to school library advocacy. The search was limited to literature generated in the United States between 2001 and 2011, using the adoption of 
the U.S. No Child Left Behind Act (NCLB, 2001) as the latest demarcation of a distinct era of educational reform characterized by high-stakes accountability (Valli \& Buese, 2007) and defined as a major restructure and change of the core aims of education (Hanson, 2001).

The databases Education Resources Information Center (ERIC), Google Scholar and the Wilson Library Literature \& Information Science Index were searched. A total of 63 U.S. publications were found in the two databases using the keywords "school libr* advoc* and teacher libr* advoc*" with publication dates between 2001 and 2011.

Next, the articles were organized into nine categories (see Appendix A for a full accounting of the articles) outlined in Ewbank (2011). Table 2 describes the categories.

A sample of the data set (one article from each of the nine categories) was used to construct a conceptual matrix. Each article was mapped to identify the advocacy effort, the goal, the stakeholder, and the result. Articles were viewed holistically prior to quantifying and tallying the results. See Table 3 for an example of this method.

After developing the conceptual matrix with the sample of nine articles, it was applied to the entire data set. As the data were analyzed, it became evident that some articles referenced advocacy but did not fit the operational definition provided by the American Association of School Librarians. Those articles that did not fit the definition were excluded from the study and the final data set totaled 47 articles.

After applying the conceptual matrix, each article was analyzed for the advocacy efforts undertaken, the responsible parties, the target populations, goals and reasons for advocacy within the literature. The results of this analysis are provided in the next section.

\section{Results}

\subsection{What advocacy efforts are being undertaken?}

In all, 372 separate advocacy efforts were found within the data set. Of these, 168 efforts outlined tangible results of advocacy efforts while 204 efforts described strategies or techniques for advocacy but did not identify an outcome. The advocacy efforts were separated into two phases: planning and acting, where "planning" identified efforts that were passive in nature and "acting" identified efforts that were active in nature. However, $36 \%(n=133)$ of the efforts could not be categorized as planning or acting. Table 4 shows the frequency of each type of effort.

\subsection{Who is responsible for advocacy?}

Among 372 distinct advocacy efforts, $64 \%$ ( $n=238$ ) were undertaken by school librarians. Over $83 \%$ of the total efforts were conducted by an actor connected to the school library field (school librarians, professional organizations, and pre-service school librarians). Table 5 shows the frequency of responsible actors.

Table 2

Preliminary categorization of school library advocacy.

\begin{tabular}{ll}
\hline Category & $\begin{array}{l}\text { Number (percentage) of } \\
\text { Articles }\end{array}$ \\
\hline Strategies and techniques for advocacy & $20(32 \%)$ \\
Advocacy by non-librarians & $7(11 \%)$ \\
Dispositions of school librarians who are advocates & $9(14 \%)$ \\
Evidence-based practice as an advocacy tool & $8(13 \%)$ \\
Advocacy involving school administrators & $6(10 \%)$ \\
Advocacy by professional associations & $4(6 \%)$ \\
Legislative or political advocacy & $4(6 \%)$ \\
Localized reports of advocacy initiatives & $4(6 \%)$ \\
Empirical studies of advocacy & $1(1 \%)$ \\
Total & $63(100 \%)$ \\
\hline
\end{tabular}

\subsection{Who are the target populations of advocacy described in the literature?}

The school community in general $(n=78,21 \%)$ was the most predominant target population in the literature. The school community includes administrators, staff, teachers, and students and is described in general terms in the articles analyzed. Legislators or politicians $(n=$ $66,18 \%$ ) were also a frequent audience. School librarians were also a target population for advocacy. Overall, 60 specific efforts (16\%) did not specify a target population. School administrators, specifically, were a target population of $9 \%$ of the efforts and teachers, specifically, were targeted in $3 \%$ of the efforts.

\subsection{What are the goals of advocacy described in the literature?}

The advocacy goal mentioned the most frequently in the literature was enhancing awareness $(n=118,32 \%)$. Specifically, the reasons for enhancing awareness were involved in keeping the general school community informed $(n=30)$, using various communication tools, such as websites, blogs and written communication $(n=21)$, improving legislators' understanding $(n=13)$, having events such as library days and story festivals $(n=12$.), and attending meetings and presentations $(n=11)$. The general value of the school library $(n=53)$, understanding of the library program $(n=41)$, and the positive impact of school library program $(n=24)$ were talking points for the goals of advocacy.

Creating relationships was the second most prevalent goal in the literature ( $n=64,17 \%)$. This goal included collaborating with principals and teachers $(n=18)$, belonging to a professional association $(n=13)$, a strong communication network with other librarians within the district, statewide, and nationwide $(n=11)$, presenting appreciation and heartfelt gratitude $(n=6)$, and building relationships with legislators $(n=5)$.

The next frequent goal of school advocacy efforts was building influence $(n=38,10 \%)$. This goal encompassed presenting at conferences $(n=9)$, becoming a member in an educational group $(n=7)$, gathering petitions $(n=7)$, and forming a group for advocacy $(n=5)$.

The other goals of advocacy efforts in the literature were providing advocacy tips $(n=27,7 \%)$, strengthening the library program through strategic planning and fundraising $(n=25,7 \%)$, demonstrating quality school library programs $(n=22,6 \%)$, and gathering evidence about library programs make a difference in a school ( $n=21,6 \%$, i.e. gathering the data and analyzing the information).

\subsection{What are the reasons for advocacy?}

We analyzed the reasons for advocacy in each article. Of 47 articles, 27 mentioned a reason for advocacy. The reason for advocacy typically stemmed from a crisis situation, or a perceived deficit in understanding of the role of the school librarian. Articles analyzed reveal that budget reductions $(n=6)$ or loss of personnel ( $n=10)$ were the primary reasons for advocacy. Reasons for loss of personnel and budget reductions cited in the literature include a lack of understanding about the role of library media specialists as teachers $(n=11)$ and ambiguous categorization about whether librarians are instructional or support staff $(n=7)$.

\section{Discussion}

\subsection{The need for empirical work on school library advocacy}

Of the 47 articles we analyzed, only one empirical article was found. A dearth of empirical literature in advocacy suggests that librarians and other stakeholders are acting without a sufficient understanding of why or how advocacy works. While the impact studies provide a rich justification for the existence of quality school library programs staffed with a credentialed school librarian, we do not know the effectiveness of advocacy beyond what is reported in the practitioner literature. This absence of empirical research implies that the topic of school library advocacy is undertheorized and could benefit from future studies. 
Table 3

Conceptual matrix.

\begin{tabular}{|c|c|c|c|c|}
\hline Citation & Actors & Stakeholders & Efforts & Results \\
\hline Whelan, 2008 & $\begin{array}{l}\text { Parents, Librarians, } \\
\text { Teachers }\end{array}$ & Public, legislators & $\begin{array}{l}\text { - Online petition } \\
\text { - Editorials and in the media } \\
\text { - Address the school board } \\
\text { - Formed a group for advocacy } \\
\text { - Reached out to various media outlets } \\
\text { - Cultivate relationships with legislators } \\
\text { - Elected official joined and become a partner, } \\
\text { education committee wrote a letter } \\
\text { - Calls, letters, emails (to legislators) }\end{array}$ & $\begin{array}{l}\text { - In less than two weeks, } 1400 \text { people signed their online petition } \\
\text { - Made people take notice and put group on the map with key } \\
\text { legislators } \\
\text { - Education leaders agreed to sponsor a bill to fund school } \\
\text { library program }\end{array}$ \\
\hline
\end{tabular}

It is likely that what is reported in the published practitioner literature is but a small fraction of the advocacy taking place around the United States. A descriptive case study approach (Yin, 2008) may be the best way to tease out the complexities of situations where advocacy is employed. This approach is ideal for understanding complex and contextualized situations. Yin describes four applications of a descriptive case study. First, the method can describe real-life decisions that explain complex causal links. Second, a case study can describe the context in which the decision occurred. Third, it can describe the decision itself. Finally, descriptive case studies can explore situations in which the decision being evaluated has no clear set of outcomes.

In an analysis of 372 specific advocacy efforts, over half (54\%) did not identify an outcome. This is consistent with the initial categorization of the literature, which emphasized strategies and techniques for advocacy over reports of what has worked to build and maintain quality school library programs in the face of budget cuts. The literature is full of best practices, but these best practices are not field tested or proven effective, according to the analysis. Perhaps this is because advocacy efforts are context-dependent; it may be difficult or impossible to identify causation. However, using a case study method, researchers may be able to build theory about what works in advocacy and why.

Moreover, the definition of advocacy is not agreed upon in the literature. The original sample contained 63 articles that mentioned advocacy. Of these, 15 articles that did not fit the operational definition of advocacy as established by AASL (2005) were eliminated. This may indicate that the definition of advocacy is not widely accepted in the profession. More research on the definition of advocacy as it pertains to the school library context is needed, and the field would benefit from additional research on how the definition is applied throughout the profession.

\subsection{The role of the library professional as an actor in advocacy}

In the literature analyzed there is an overrepresentation of library professionals as the sole actor in advocacy. In this analysis, 83\% of advocacy activities undertaken were initiated by school librarians or an

Table 4

Types of advocacy efforts.

\begin{tabular}{lc}
\hline Types of advocacy efforts & $\mathrm{N}=372$ \\
\hline Planning stage & $21(6 \%)$ \\
Collecting evidence, preparing strong resources & $16(4 \%)$ \\
Attending professional development & $12(3 \%)$ \\
Being a member of association or task force & $11(3 \%)$ \\
Creating and organizing a support group & $8(2 \%)$ \\
Creating and sharing visions and goals & \\
Acting stage & $67(18 \%)$ \\
Involving principals and teachers & $29(8 \%)$ \\
Communicating with decision makers & $25(7 \%)$ \\
Reading/distributing information on school library advocacy & $25(7 \%)$ \\
Attending conferences and making presentations & $14(4 \%)$ \\
Attending library legislative days or other organized events & $11(3 \%)$ \\
Collaborating and networking with other librarians & $133(36 \%)$ \\
Other & \\
\hline
\end{tabular}

individual in the school library field. A key feature of the AASL definition is "building partnerships so that others will act for and with you." Only $5 \%$ of the actors identified in the literature were parents, and just $3 \%$ were administrators.

This trend is of concern for school library advocates. Library Power, an initiative in nineteen communities across the United States and supported by the Dewitt-Wallace/Reader's Digest Fund in the late 1990s, demonstrated that advocacy for the tenets of strong school libraries (collaboration, flexible scheduling, inquiry learning, etc.) happened at the coalition level (Zweizig \& Hopkins, 1999). The librarian-principal team partnered with formal entities in the educational community to garner support for the goals of the initiative. In the communities that had broad coalition support, the Library Power initiative was more likely to be sustained (Zweizig \& Hopkins, 1999). This demonstrates that in order for school library advocacy to be successful, it is imperative that the librarian enlists broad support from the community, including principals, teachers, and parents. Librarians cannot sustain advocacy initiatives on their own.

Moreover, Gary Hartzell, a professor emeritus of educational administration and a former school administrator, reinforces the need for school librarians to build influence with administrators and teachers (Hartzell, 2003). He states, "research shows that association with and support from people at upper levels in the hierarchy enhance a person's credibility and leverage with co-workers; a strong relationship with the principal can help you become more visible while it aids in the development of alliances" (Hartzell, 2003, p.93).

Hartzell (2012) expresses concern that the strategies that school library advocates are currently employing are not working. He suggests a new tactic: advocating for school libraries in preservice educational administration programs and professional associations to which administrators belong (Hartzell, 2012). To accomplish this, Hartzell suggests that library media faculty publish in refereed journals that educational administration faculty read and developing partnerships with educational administration associations who have a broad reach with practicing K-12 administrators (Hartzell, 2012).

Another way to explore the phenomenon is to examine both the ALA and AASL competencies for advocacy to see whether preservice librarians are being trained in a manner that is consistent with the AASL definition for advocacy.

The ALA/AASL Standards for Initial Preparation of School Librarians (http://www.ala.org/aasl/files/aasleducation/schoollibrary/2010_

Table 5

Frequency of responsible actors $(\mathrm{N}=372)$.

\begin{tabular}{lrr}
\hline Actors & N & $\%$ \\
\hline School librarians & 238 & $64 \%$ \\
Professional organization & 69 & $19 \%$ \\
Learning community & 20 & $5 \%$ \\
Parents & 18 & $5 \%$ \\
Higher education & 12 & $3 \%$ \\
Administrators & 10 & $3 \%$ \\
Pre-service librarians & 5 & $1 \%$ \\
\hline
\end{tabular}


standards_with_rubrics_and_statements_1-31-11.pdf) have a section on leadership and advocacy. In this section the competency states.

Candidates identify stakeholders within and outside the school community who impact the school library program. Candidates develop a plan to advocate for school library and information programs, resources, and services.

When one compares the AASL definition of advocacy to the standards for initial preparation of school librarians there appears to be a subtle yet important difference. While the AASL definition of advocacy asks librarians to "build partnerships so that others will act for and with you," the ALA/AASL competencies for pre-service librarians stop short of asking this of its candidates. It is possible that the ALA/AASL competencies do not go far enough in preparing pre-service librarians to take action, rather than simply identify stakeholders and develop a plan to advocate.

By extrapolation, if school library advocates were applying the AASL definition of advocacy, there may be higher numbers of parents, teachers, and administrators involved in advocacy efforts. By examining the published literature there is much that is unknown about individual advocacy situations. Perhaps those who have successful advocacy programs where individuals are acting for and with librarians are not writing about their experiences. Again, a case study approach may be the best way to unpack individual, contextualized situations where others are acting for and with the library.

\section{Limitations}

This article attempts to find a baseline understanding of school library advocacy, using a sample of published articles in the United States between 2001-2011 available via several major databases. The search was comprehensive but not exhaustive. Gray literature and other ephemeral publications (e.g. web sites, conference reports and papers, state newsletters) were excluded from the review. Future research should include a larger data set of international scope that includes gray literature and other ephemeral publications.

Additionally, the study was limited to articles and publications that specifically mentioned the word "advocacy" and aligned with the 2005 AASL definition. However, there is a body of literature that reports on specific aspects of advocacy (such as collaboration efforts and building partnerships) that was not studied in this exploratory conceptual content analysis. Future studies should seek to broaden the scope of data collection to include publications about specific aspects of advocacy that may not use the term.

\section{Conclusion}

Of special consideration is the dearth of research literature about school library advocacy. Finding one research article published during the ten-year scope of the literature search suggests that the field must mature to include more research on the topic. Additionally, the lack of consensus in a definition of advocacy was another outcome of the study. This suggests that practitioners and researchers both must come to consensus on the true nature of advocacy. The development of a precise definition may assist in developing a more unified front that clearly defines the tactics for the promotion of the school library profession. School library educators must incorporate advocacy education into their curriculum, developing cohesive standards for teaching preservice librarians about advocacy. Practitioners should consider specific, differentiated strategies for targeting school administrators, teachers, parents, and policymakers.

However, without further investigation of the topic, it is difficult to determine what does or does not work in promoting the profession. In conclusion, we hope that this exploratory conceptual content analysis of the existing literature on advocacy in the United States begins a line of inquiry into how advocacy is positioned in school librarianship. Researchers should address the dearth of empirical and theoretical work on both the practice and impact of advocacy on the profession. A better understanding of advocacy for school libraries matters to librarians, teachers, administrators, and most importantly to children and their families.

\section{Appendix A. Categorization of School Library Advocacy Literature (based on Ewbank, 2011).}

\begin{tabular}{|c|c|}
\hline Category & Publications \\
\hline Advocacy by non-librarians & $\begin{array}{l}\text { Hultgren, J. (2009). The friends of Northside ISD libraries sets sail. Library Media Connection, 27(5), 38-39. } \\
\text { Kaaland, C. (2009). A campaign of gratitude. School Library Media Activities Monthly, 25(9), 52-53. } \\
\text { Kenney, B. (2008). To Spokane, with love and gratitude. School Library Journal, 54(6), 11. } \\
\text { Whelan, D. L. (2008). Three Spokane moms save their school libraries. School Library Journal, 54(9), 36-41. } \\
\text { Whelan, D. (2008). Mesa (AZ) School Board Votes to Eliminate School Librarians. School Library Journal. Retrieved from } \\
\text { http://www.schoollibraryjournal.com/slj/articlesfunding/859355-347/mesa_az_school_board_votes.html.csp }\end{array}$ \\
\hline Advocacy by professional associations & $\begin{array}{l}\text { Johns, S. K. (2007). Advocacy: AASL puts the puzzle together. Knowledge Quest, 36(1), 4-7. } \\
\text { Williams, J. L. (2006). Advocacy: The first step in achieving it all. Knowledge Quest, 34(3), 4-6. }\end{array}$ \\
\hline $\begin{array}{l}\text { Advocacy involving school } \\
\text { administrators }\end{array}$ & $\begin{array}{l}\text { Ewbank, A. (2011). Advocacy for the school library media profession: Results of a U.S. national survey. School Libraries Worldwide, } \\
\text { 37(2), 41-58. } \\
\text { Gallagher-Hayashi, D. (2001). Moving the fence: Engaging your principal in your school library program. Teacher Librarian, 28(5), 13-17. } \\
\text { Hartzell, G. (2007). How do decision-makers become library media advocates? Knowledge Quest, 36(1), 32-35. } \\
\text { Harvey, C. A. (2009). Principal perspective, part 3: Advocacy and shared vision. School Library Media Activities Monthly, 25(6), 51-53. } \\
\text { Kachel, D. E. (2003). Partners for success: A school library advocacy training program for principals. Knowledge Quest, 32(2), 17-19. }\end{array}$ \\
\hline $\begin{array}{l}\text { Dispositions of school librarians who } \\
\text { are advocates }\end{array}$ & $\begin{array}{l}\text { Barron, D. D. (2003). The curse of the invisible library media specialist. School Library Media Activities Monthly, 19(5), 48-51. } \\
\text { Dickinson, G. (2007). The question... can I achieve excellence as a school librarian if I am not naturally an enthusiastic extrovert? } \\
\text { Knowledge Quest, 36(1), 70-71. } \\
\text { Levitov, D. (2007). One library media specialist's journey to understanding advocacy: A tale of transformation. Knowledge Quest, 36(1), } \\
\text { 28-31. } \\
\text { Martin, A. (2007). The evolution of the librarian as advocate: Are advocates born or developed? Knowledge Quest, 36(1), 16-19. } \\
\text { Minkel, W. (2002). Making every librarian a leader. School Library Journal, 48(10), 46-49. } \\
\text { Moreillon, J., \& Misakian, J. E. (2007). Preservice teacher-librarian education: Learning the character of an advocate. Knowledge Quest, } \\
\text { 36(1), 20-23. } \\
\text { Schuckett, S. (2007). The making of an advocate: My life in the arena. Knowledge Quest, 36(1), 36-39. }\end{array}$ \\
\hline
\end{tabular}




\begin{tabular}{|c|c|}
\hline Category & Publications \\
\hline & Stripling, B. (2007). The dance of leadership and advocacy. Knowledge Quest, 36(1), 54-55. \\
\hline Empirical studies of advocacy & $\begin{array}{l}\text { Ewbank, A. (2011). Advocacy for the school library media profession: Results of a U.S. national survey. School Libraries Worldwide } \\
\text { 37(2), 41-58. }\end{array}$ \\
\hline \multirow[t]{4}{*}{ Legislative or political advocacy } & $\begin{array}{l}\text { Ewbank. A., \& Moreillon, J. (2006). The } 65 \% \text { Solution is no solution for schools or library media centers. School Library Media Activities } \\
\text { Monthly. June, } 22-24 \text {. }\end{array}$ \\
\hline & Kaaland, C. (2010a). Legislator in the library day: A model for legislative advocacy. School Library Monthly, 26(7), 44-46. \\
\hline & Lance, K. C. (2006). The outsiders: It's not just the money. School Library Journal, 52(9), 52. \\
\hline & Young, R. (2009). Attending National Library Legislative Day: Why is it important? Library Media Connection, 27(5), 30-31. \\
\hline \multirow{3}{*}{$\begin{array}{l}\text { Localized reports of advocacy } \\
\text { initiatives }\end{array}$} & Burris, M. (2006). The evolution of an advocacy group: The British Columbia coalition for school libraries. PNLA Quarterly, 70(4), 12-13. \\
\hline & Logan, D. K. (2009). Making the impossible dream come true: The Ohio quest to serve students. Teacher Librarian, 37(1), 40-42. \\
\hline & Logan, D. K. (2010). Staying the course: Racing for Ohio's students. Library Media Connection, 28(4), 12-16. \\
\hline \multirow[t]{23}{*}{ Strategies and techniques for advocacy } & $\begin{array}{l}\text { Adams, H. R. (2011). The intellectual freedom calendar: Another advocacy plan for the school library. School Library Monthly, 27(7), } \\
52-53 .\end{array}$ \\
\hline & Baxter, V. (2007). Library media advocacy through grant writing. School Library Media Activities Monthly, 24(2), 45-47. \\
\hline & Bush, G. (2007). Telling our school library story. Knowledge Quest, 36(1), 40-43. \\
\hline & Collins, C. (2010). Survival tactics for the warrior librarian. Library Media Connection, 29(3), 18-19. \\
\hline & Foote, C. (2010). Everyday advocacy: Making a case for libraries is easy with web tools. School Library Journal, 56(8), 28-30. \\
\hline & Freda, C. (2007). Promoting your library program: Getting the message out. Knowledge Quest, 36(1), 48-51. \\
\hline & $\begin{array}{l}\text { Hainer, E. (2005). Advocacy: School librarians and advocacy: Part of the problem, or part of the solution? Knowledge Quest, 33(5), } \\
\text { 27-29. }\end{array}$ \\
\hline & Hand, D. (2008). What can teacher-librarians do to promote their work and the school library media program? Keep everyone in the \\
\hline & loop: Constant advocacy. Teacher Librarian, 36(2), 26-27. \\
\hline & Howard, J. K. (2009). Advocacy through relationships. School Library Monthly, 26(2), 44-45. \\
\hline & Johnson, D. (2005). When your job is on the line: Strategies for assisting library media specialists whose positions are in jeopardy. \\
\hline & Library Media Connection, 23(5), 44. \\
\hline & Kaaland, C. (2010b). Recruitment to the Profession: A form of advocacy. School Library Monthly, 26(10), 44-46. \\
\hline & Kaaland, C. (2011). Proactive advocacy: Emergency preparedness for the school library. School Library Monthly, 27(4), 49-51. \\
\hline & Kelly, S. (2008). Getting a seat at the table-an ongoing effort. School Library Media Activities Monthly, 25(3), 23-25. \\
\hline & Lehman, K. (2002). Promoting library advocacy and information literacy from an invisible library. Teacher Librarian, 29(4), 27-30. \\
\hline & Leverett, L. (2001). Extending your influence by “spreading the word”. Book Report, 20(1), 24-26. \\
\hline & Levitov, D. D. (2009). Advocacy links... tools to use. School Library Media Activities Monthly, 25(7), 4. \\
\hline & Schuckett, S. (2005). Be a school library advocate. Library Media Connection, 23(6), 24. \\
\hline & Terrell, N. (2010). Speaking up. Library Media Connection, 29(1), 28-29. \\
\hline & Vanneman, S. (2007). Advocacy: Sparks and threads. Knowledge Quest, 35(4), 36-38. \\
\hline & Wallace, V. (2004). What works? Marketing? Public relations? Yes, and more advocacy background. School Library Media Activities \\
\hline & Monthly, 20(9), 49-51. \\
\hline
\end{tabular}

\section{References}

American Library Association (2011a). School library provision included in reintroduction of SKILLS Act. Retrieved from http://www.districtdispatch.org/2011/07/schoollibrary-provision-included-in-reintroduction-of-skills-act/

American Library Association (2011b). President's proposed American Jobs Act to include funds for school libraries. Retrieved from http://www.districtdispatch.org/2011/09/ president\%E2\%80\%99s-proposed-american-jobs-act-to-include-funds-for-schoollibraries/

American Library Association (2012). ALA wastes no time: Our work on digital literacy. Retrieved from http://www.districtdispatch.org/2012/05/ala-wastes-no-time-ourwork-on-digital-literacy/

Asselin, M. (2002). Evidence-based practice. Teacher Librarian, 30(1), 53-54.

Baum, J. A. C., \& Singh, J. V. (Eds.). (1994). Evolutionary dynamics of organizations. New York, NY: Oxford University Press.

Beile, P. M. (2009). Content analysis: De-constructing intellectual packages. In D. Cook, \& L. Farmer (Eds.), Observe, reflect, act: A primer on applied qualitative research by librarians. Chicago, IL: ACRL.

Benham, J. L. (2011). Music advocacy: Moving from survival to vision. Lanham, MD: Rowman \& Littlefield.

Berg, K. (2010). Justifying physical education based on neuroscience evidence. Journal of Physical Education, Recreation \& Dance (JOPERD), 81(3), 24-29.

Blankenship, B. T., \& Solmon, M. A. (Eds.). (2004). Physical education, physical activity, and public health: Learning from the past, building for the future. Journal of Teaching in Physical Education, 23(4).

Block, D. G. (2010). Advocacy: Staging a recovery for music education. Teaching Music 17(4), 22-22.

Boyce, B. A., \& Rikard, G. L. (2008). A comparison of supply and demand for PETE faculty: The changing landscape. Research Quarterly for Exercise and Sport, 79(4), $540-545$.

Braxton, B. (2003). Putting evidence-based advocacy to work. Teacher Librarian, 31(2), 41-42.

Burris, M. (2006). The evolution of an advocacy group: The British Columbia coalition for school libraries. PNLA Quarterly, 70(4), 12-13.

Busch, C., De Maret, P., Flynn, T., Kellum, R., Le, S., Meyers, B., et al. (2005). Content analysis. Writing@CSU. Colorado State University Department of English Retrieved from http://writing.colostate.edu/guides/research/content/.

Bush, G. (2007). Telling our school library story. Knowledge Quest, 36(1), 40-43.

Clemens, E. V., Shipp, A., \& Kimbel, T. (2011). Investigating the psychometric properties of school counselor self-advocacy questionnaire. Professional School Counseling, 15(1), 34-44. http://dx.doi.org/10.5330/PSC.n.2011-15.34
Croneis, K. S., \& Henderson, P. (2002). Electronic and digital librarian positions: A content analysis of announcements from 1990 through 2000. Journal of Academic Librarianship, 28(4), 232-237. http://dx.doi.org/10.1016/S0099-1333(02)00287-2

Dodds, P. (2006). Physical education teacher education policy. In D. Kirk, D. McDonald, \& M. O'Sullivan (Eds.), The handbook of physical education. Thousand Oaks, CA: Sage Publications.

Dodson, T. (2009). Advocacy and impact: A comparison of administrators' perceptions of the high school counselor role. Professional School Counseling, 12(6), 480-487, http:// dx.doi.org/10.5330/PSC.n.2010-12.480.

Dooley, J. (1995). Cultural aspects of systemic change management. Retrieved from http://www.well.com/user/dooley/culture.pdf

Elpus, K. (2007). Improving music education advocacy. Arts Education Policy Review, 108(3), 13-18. http://dx.doi.org/10.3200/AEPR.108.3.13-18

Eriksen, K. P. (1997). Counselor advocacy: Where we are and what it takes to move ahead (Doctoral dissertation). Retrieved from Proquest Dissertations and Theses. (9736859).

Eriksen, K. (1999). Counselor advocacy: A qualitative analysis of leaders' perceptions, organizational activities, and advocacy documents. Journal of Mental Health Counseling, 21(1), 33-49.

Ewbank, A. (2011). Advocacy for the school library media profession: Results of a U.S. national survey. School Libraries Worldwide, 37(2), 41-58.

Farmer, L. S. J. (2006). Library media program implementation and student achievement Journal of Librarianship and Information Science, 38(1), 21-32. http://dx.doi.org/10. 1177/0961000606060957

Field, J. E., \& Baker, S. (2004). Defining and examining school counselor advocacy Professional School Counseling, 8(1), 56.

Gard, M., \& Wright, J. (2001). Managing uncertainty: Obesity discourses and physical education in a risk society. Studies in Philosophy and Education, 20(6), 535-549. http:// dx.doi.org/10.1023/A:1012238617836

Gaver, M. V. (1963). Effectiveness of centralized library service in elementary schools (2nd ed.). New Brunswick, NJ: Rutgers University Press.

Giambra, C. (1998). "Libraries change lives": Advocacy campaign begins in New York Emergency Librarian, 25, 18-19.

Haas, S. W., \& Grams, E. S. (2000). Readers, authors, and page structure: A discussion of four questions arising from a content analysis of web pages. Journal of the American Society for Information Science, 51(2), 181-192.

Hainer, E. (2005). Advocacy: School librarians and advocacy: Part of the problem, or part of the solution? Knowledge Quest, 33(5), 27-29.

Hanson, M. (2001). Institutional theory and educational change. Educational Administration Quarterly, 37(5), 637-661. http://dx.doi.org/10.1177/00131610121969451

Hartzell, G. (2003). Building influence for the school librarian: Tenets, targets, and tactics (2nd ed.). Worthington, OH: Linworth. 
Hartzell, G. (2012). The need to shift and widen school library advocacy efforts: An opinion piece. Library Media Connection, 30(6), 12-13.

Hill, W. (2002). Advocacy in music education. Teaching Music, 10(2), 5.

Holmberg, D. J. (2012). The perceived status of the professional school counselor's advocacy role, training, and activities (Doctoral dissertation). Retrieved from Proquest Dissertations \& Theses. (3519699).

Ireland, L. (2001). The impact of school library services on student academic achievement: An annotated bibliography (5th ed.). Retrieved from http://eric.ed.gov/PDFS/ED450807. pdf

Julien, H., Pecoskie, J., \& Reed, K. (2011). Trends in information behavior research, 1999-2008: A content analysis. Library and Information Science Research, 33, 19-24. http://dx.doi.org/10.1016/j.lisr.2010.07.014

Kenney, B. (2008). To Spokane, with love and gratitude. School Library Journal, 54(6), 11

Kircher, R. L. (2007). Counselor educators' perceptions of the preparation of school counselors for advocacy (Doctoral dissertation). Retrieved from Proquest Dissertations \& Theses. (3259312).

Kiselica, M., \& Robinson, M. (2001). Bringing advocacy counseling to life: The history, issues, and human dramas of social justice work in counseling. Journal of Counseling and Development, 79(4), 387-397.

Krippendorff, K. (2004). Content analysis: An introduction to its methodology. Thousand Oaks, CA: Sage.

Lance, K. C. \& Schwarz, B. (2012). How Pennsylvania school libraries pay off: Investments in student achievement and academic standards. PA School Library Project. Philadelphia: PA: Health Sciences Libraries Consortium. Retrieved from http://paschoollibraryproject.org/ research

Lance, K. C., Rodney, M. J., \& Hamilton-Pennell, C. (2005). Powerful libraries make powerful learners: The Illinois study. Canton, IL: Illinois School Library Media Association. Retrieved from http://www.alliancelibrarysystem.com/illinoisstudy/

Leverett, L. (2001). Extending your influence by “spreading the word”. Book Report, 20(1) 24-26.

Loertscher, D. V., \& Todd, R. J. (2003). We boost achievement! Evidence-based practice for school library media specialists. Salt Lake City, UT: Hi Willow Research \& Publishing.

Logan, D. K. (2006). Being heard... advocacy + evidence + students = impact! Schoo Library Media Activities Monthly, 23(1), 46-48.

Lynch, B., \& Smith, K. (2001). The changing nature of work in academic libraries. College and Research Libraries, 62(5), 407-420.

March, J. (1994). The evolution of evolution. In J. Baum, \& J. Singh (Eds.), Evolutionary dynamics of organizations (pp. 39-49). New York: Oxford University Press.

Mark, M. L. (2002). A history of music education advocacy. Music Educators Journal, 89(1), 44-48.

Mark, M. L. (2005). Why music? Essays on the importance of music education and advocacy: Why does our profession need advocacy? International Journal of Music Education, 23(2), 94-98. http://dx.doi.org/10.1177/0255761405052399

Marsh, E. E., \& White, M. D. (2006). Content analysis: A flexible methodology. Library Trends, 55(1), 22-45. http://dx.doi.org/10.1353/lib.2006.0053

McTavish, D., \& Pirro, E. (1990). Contextual content-analysis. Quality E' Quantity, 24(3) 245-265. http://dx.doi.org/10.1007/BF00139259

Myers, J., \& Sweeney, T. (2004). Advocacy for the counseling profession: Results of a national survey. Journal of Counseling and Development, 82(4), 466-471.

Myers, J., Sweeney, T., \& White, V. (2002). Advocacy for counseling and counselors: A professional imperative. Journal of Counseling and Development, 80(4), 394-402.

No Child Left Behind Act of 2001 (2001). 20 U.S.C. $\S 6319$.

Ontario Library Association (2006). School libraries and student achievement in Ontario. Toronto, ON: Ontario Library Association. Retrieved from http://www.accessola.com/ data/6/rec_docs/137_eqao_pfe_study_2006.pdf

Peterson, M., \& Spencer, M. (1991). Understanding academic culture and climate. In M. Peterson (Ed.), ASHE reader on organization and governance (pp. 140-155). Needham Heights, MA: Simon \& Schuster.

Ratts, M. J., DeKruyf, L., \& Chen-Hayes, S. F. (2007). The ACA advocacy competencies: A social justice advocacy framework for professional school counselors. Professional School Counseling, 11(2), 90-97. http://dx.doi.org/10.5330/PSC.n.2010-11.9

Rodney, M. J., Lance, K. C., \& Hamilton-Pennell, C. (2002). Make the connection: Quality school library media programs impact academic achievement in Iowa. Bettendorf, IA
Iowa Area Education Agencies 2002. Retrieved from http://www.iowaaeaonline. org/pages/uploaded_files/Make\%20The\%20Connection.pdf

Rodney, M. J., Lance, K. C., \& Hamilton-Pennell, C. (2003). The impact of Michigan school libraries on academic achievement: Kids who have libraries succeed. Lansing, MI: Library of Michigan. Retrieved from http://www.michigan.gov/documents/hal_lm schllibstudy03_76626_7.pdf

Russell, P. (2004). Information literacy and education policy: An instrumental case study of the Ontario public school curriculum. Unpublished masters' thesis, Canada: University of Toronto.

Schuckett, S. (2005). Be a school library advocate. Library Media Connection, 23(6), 24.

Small, R. V., Shanahan, K. A., \& Stasak, M. (2010). The impact of New York's school libraries on student achievement and motivation: Phase III. School Library Media Research, 13 Retrieved from http://www.ala.org/aasl/sites/ala.org.aasl/files/content/ aaslpubsandjournals/slr/vol13/SLR_ImpactofNewYork.pdf

Smith, E. G. (2001). Texas school libraries: Standards, resources, services, and students' performance. Austin, TX: Texas State Library and Archive Commission. Retrieved from http://www.tsl.state.tx.us/ld/pubs/schlibsurvey/index.html

Stanec, A. S. (2008). Assessment for advocacy: Documenting student learning in secondary physical education. Physical and Health Education Journal, 73(4), 6.

Stansbury, M. C. (2002). Problem statements in seven LIS journals. Library and Information Science Research, 24, 157-168. http://dx.doi.org/10.1016/S0740-8188(02)00110-X

Tappe, M. K., \& Galer-Unti, R. A. (2001). Health educators' role in promoting health literacy and advocacy for the 21st century. Journal of School Health, 71(10), 477-482. http://dx.doi.org/10.1111/j.1746-1561.2001.tb07284.x

Thickstun, K. (2011). It's all your business: Got milk? Got music. American Music Teacher, 60(6), 51.

Todd, R. J. (2003). School libraries evidence: Seize the day, begin the future. Library Media Connection, 22(1), 12-18.

Todd, R. J. (2006). School libraries and evidence-based practice: An integrated approach to evidence. School Libraries Worldwide, 12(2), 31-37.

Todd, R. J. (2008a). A question of evidence. Knowledge Quest, 37(2), 16-21.

Todd, R. (2008b). The evidence-based manifesto. School Library Journal, 54(4), 38-43.

Todd, R., Gordon, C., \& Lu, Y. (2012). The New Jersey study of school libraries: One common goal- student learning. Retrieved from http://www.njasl.info/cissl-study/

Trost, S., \& van der Mars, H. (2009). Why we should not cut PE. Educational Leadership, $67(4), 60-65$.

Valli, L., \& Buese, D. (2007). The changing roles of teachers in an era of high-stakes accountability. American Educational Research Journal, 44(3), 519-558.

von Winter, T. (2011). Advocacy. In B. Badie, D. Berg-Schlosser, \& L. Morlino (Eds.), International encyclopedia of political science (pp. 29-34). Thousand Oaks, CA: SAGE Publications, Inc. http://dx.doi.org/10.4135/9781412959636.n6

Williams, J. L. (2006). Advocacy: The first step in achieving it all. Knowledge Quest, 34(3), 4-6.

Yin, R. K. (2008). Case study research: Design and methods. Los Angeles, CA: Sage Publications.

Zweizig, D., \& Hopkins, D. (1999). Lessons from library power: Enriching teaching and learning. Engelwood, CO: Libraries Unlimited.

Ann Dutton Ewbank is an assistant professor at Montana State University. She received her PhD from Arizona State University and her master of library science from the University of Arizona. She is a past president of the Arizona (USA) Library Association and is active in the American Library Association and American Association of School Librarians.

Ja Youn Kwon is a PhD student in the Mary Lou Fulton Teachers College at Arizona State University, USA and studies physical education. She received her master of science at Yonsei University in Korea. She has presented at the International Association of School Librarianship conference, the American Educational Research Association conference, and has published in the Journal of Teaching in Physical Education. 